\section{Synthesis and bioactivity evaluation of novel benzamide derivatives containing a diphenyl ether moiety}

\author{
Mingjing Chen, ${ }^{1}$ Hong Jin, ${ }^{2, *} \mathrm{Ke} \mathrm{TAO}^{2}$ \\ and Taiping $\mathrm{Hou}^{2}$ \\ ${ }^{1}$ Key Laboratory of Green Chemistry and Technology of Ministry of \\ Education, College of Chemistry, Sichuan University, \\ Chengdu, 610064, P. R. China \\ ${ }^{2}$ Key Laboratory of Bio-Resource and Eco-environment of Ministry of \\ Education, College of Life Sciences, Sichuan University, \\ Chengdu, 610064, P. R. China
}

(Received April 20, 2014; Accepted August 27, 2014)

A series of novel benzamide derivatives with a diphenyl ether moiety were synthesized and evaluated for antifungal and insecticidal activities on the basis of the principle of splicing-up bioactive substructures. Most of the novel benzamide derivatives exhibited moderate to good antifungal activities against five plant pathogen fungi, and compound $\mathbf{1 7}$ has shown good antifungal activity against $S$. ampelimum with $\mathrm{EC}_{50}$ values of $0.95 \mathrm{mg} / \mathrm{L}$ and is hoped to be a potential lead compound. (c) Pesticide Science Society of Japan

Keywords: synthesis, benzamide derivatives, antifungal activity, insecticidal activity, diphenyl ether.

\section{Introduction}

Agricultural plant diseases and insect pests are two causes of major economic damage to agriculture in the world. ${ }^{1,2)}$ The fungicide market has been generally dominated since the 1970s by several chemical classes of carboxamides, methoxyacrylates, pyrimidinamines, triazoles and so on. ${ }^{3-5)}$ Carboxamide fungicides, such as the commercial fungicides benodanil, mepronil and flutolanil (Fig. 1), have played an important role in the field of agrochemicals, ${ }^{6,7)}$ can inhibit the growth of pathogenic fungi and can cause their eventual death by interfering with the respiration of the pathogen. ${ }^{8,9)}$

In our previous research, many substituted diphenyl ether derivatives were synthesized and found to have good antimicrobial activities, ${ }^{10,11)}$ and many natural diphenyl ether derivatives also elicited pharmacologically powerful activities, ${ }^{12-14)}$ such as an-

\footnotetext{
* To whom correspondence should be addressed.

E-mail: jinhong@scu.edu.cn

Published online October 28, 2014

(c) Pesticide Science Society of Japan
}

tifungal, antibiotic, antimitotic and immunosuppressive activities. ${ }^{15-17)}$

Hence, whether the amide derivatives containing a diphenyl ether moiety will have good bioactivities is of interest. To extend our research on developing novel amide derivatives as a fungicide, we have integrated a benzamide scaffold with a diphenyl ether moiety to search for novel agrochemicals with a higher potential of antifungal activities on the basis of the principle of splicing-up bioactive substructures (Fig. 2).

Here we report the synthesis of novel benzamides containing a diphenyl ether moiety and evaluation of antifungal and insecticidal activities.

\section{Materials and Methods}

1. General

All the reagents used were commercial and were used without further purification unless otherwise indicated. Analytical thin-layer chromatography and preparative thin-layer chromatography were performed with silica gel plates using silica gel 60 GF254 (Qingdao Haiyang Chemical Co., Ltd., Qingdao, Shandong Province, China). ${ }^{1} \mathrm{H}$ NMR spectra were obtained in deuterochloroform solution on a Bruker $400 \mathrm{MHz}$ spectrometer using tetramethylsilane (TMS) as an internal standard and MS data were obtained on a MALDI-TOF/TOF Mass Spectrometer (Bruker).

\section{Synthesis}

\subsection{Synthesis of 2-aryloxyanilines $(\mathbf{4 a}-\mathbf{4} f)$}

\subsubsection{Synthesis of 1-nitro-2-aryloxybenzenes $(\mathbf{3} \boldsymbol{a}-\mathbf{3} \boldsymbol{f})$}

$\mathrm{KOH}(66 \mathrm{mmol})$ was added to compounds 1a-1f $(66 \mathrm{mmol})$ at $90^{\circ} \mathrm{C}$, and the mixture was stirred for $15 \mathrm{~min}$. Then compound $2(60 \mathrm{mmol})$ was added slowly. The mixture was stirred for another $2 \mathrm{hr}$ at $150^{\circ} \mathrm{C}$. Finally, the reaction mixture was extracted with ethyl acetate, and the solvent was removed in vacuum to give compounds $3 \mathbf{a}-\mathbf{3 f}$ in yields of $86-98 \%$.

\subsubsection{Synthesis of 2-aryloxyanilines $(\mathbf{4 a}-\mathbf{4} f)$}

To a slurry mixture of iron powder $(150 \mathrm{mmol})$ and compounds 3a-3f $(50 \mathrm{mmol})$ in absolute ethanol $(40 \mathrm{~mL})$, a solution of concentrated hydrochloric acid $(5 \mathrm{~mL})$ in ethanol $(10 \mathrm{~mL})$ was added dropwise for a period of $10 \mathrm{~min}$ at $80^{\circ} \mathrm{C}$. The resulting mixture was stirred for another $2 \mathrm{hr}$ at $80^{\circ} \mathrm{C}$. Finally, the reaction mixture was alkalized by $\mathrm{NaOH}$ solution and filtered. The solvent in the collected filtrate was removed in vacuum to give crude products. The crude products were purified by column chromatography on silica gel to give compounds $\mathbf{4 a - 4 f}$ in yields of $38-51 \% .^{18,19)}$

2.2. General procedure for the preparation of carboxylic acid chloride (6)

Thionyl chloride $(15 \mathrm{~mL})$ was added to a corresponding acid $(10 \mathrm{mmol})$, and the mixture was refluxed for $1 \mathrm{hr}$. Excess thionyl 


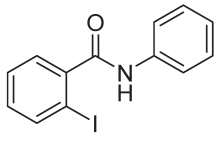

Benodanil

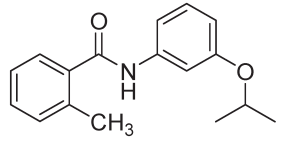

Mepronil

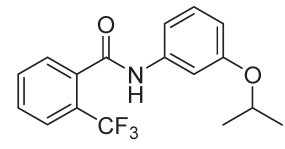

Flutolanil

Fig. 1. Commercial fungicides benodanil, mepronil and flutolanil.

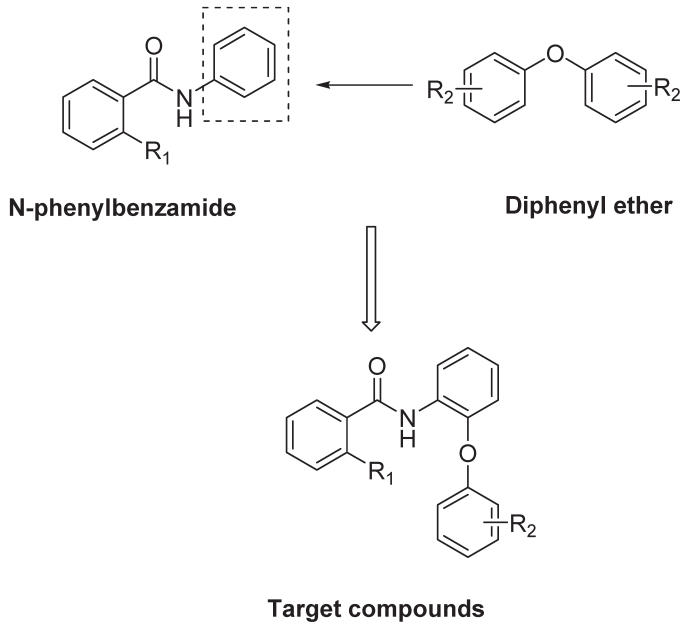

Fig. 2. Design strategy of the target compounds.

chloride was removed in vacuum. The crude product 6 was used in subsequent reactions without further purification. ${ }^{20)}$

2.3. General procedure for the synthesis of benzamide derivatives (7-19)

A mixture of $\mathrm{NaOH}$ aq. solution $(2 \mathrm{~mol} / \mathrm{L}, 20 \mathrm{~mL}), 1,4$-dioxane $(2 \mathrm{~mL})$ and compounds $\mathbf{4 a}-\mathbf{4 f}(5 \mathrm{mmol})$ was dissolved and cooled to $0^{\circ} \mathrm{C}$ in an ice bath. While stirring the mixture, compound $6(10 \mathrm{mmol})$ was added slowly. Afterward, the resulting reaction mixture was stirred for another $2 \mathrm{hr}$ at room temperature. The mixture was then extracted with ethyl acetate, and the solvent was removed in vacuum. The crude products were purified by column chromatography on silica gel to give compounds 7-19 in yields of $45.8-84.6 \% .^{21,22)}$ All the compounds are listed in Table 1 and the spectral data of ${ }^{1} \mathrm{H}$ NMR are as follows.

$N$-(2-Phenoxyphenyl)-2-methylbenzamide (7). Brown solid. Yield: $70.5 \%$. ${ }^{1} \mathrm{H}$ NMR (400 MHz, $\left.\mathrm{CDCl}_{3}\right): \delta 2.48(3 \mathrm{H}, \mathrm{s}), 6.92$ $(1 \mathrm{H}, \mathrm{d}, J=8.4 \mathrm{~Hz}), 7.05-7.07(3 \mathrm{H}, \mathrm{m}), 7.13(1 \mathrm{H}, \mathrm{t}), 7.19-7.24$ $(2 \mathrm{H}, \mathrm{m}), 7.29(2 \mathrm{H}, \mathrm{d}, J=8.0 \mathrm{~Hz}), 7.50(1 \mathrm{H}, \mathrm{d}, J=8.4 \mathrm{~Hz}), 7.76$ $(2 \mathrm{H}, \mathrm{d}, J=1.6 \mathrm{~Hz}), 8.45(1 \mathrm{H}, \mathrm{s}), 8.65(1 \mathrm{H}, \mathrm{d}, J=8.4 \mathrm{~Hz}) ; \mathrm{MS} m / z$ $304.2(\mathrm{M}+1)$.

$\mathrm{N}$-[2-(2-Chlorophenoxy)phenyl]-2-methylbenzamide (8). Brown solid. Yield: $65.6 \% .{ }^{1} \mathrm{H}$ NMR $\left(400 \mathrm{MHz}, \mathrm{CDCl}_{3}\right)$ : $\delta 2.48(3 \mathrm{H}, \mathrm{s}), 6.80(1 \mathrm{H}, \mathrm{d}, J=8.4 \mathrm{~Hz}), 6.99(1 \mathrm{H}, \mathrm{d}, J=8.4 \mathrm{~Hz})$, 7.03-7.07 (1H, t), 7.19-7.24 (2H, m), $7.29(2 \mathrm{H}, \mathrm{d}, J=8.8 \mathrm{~Hz})$, $7.50(2 \mathrm{H}, \mathrm{d}, J=2.0 \mathrm{~Hz}), 7.76(2 \mathrm{H}, \mathrm{d}, J=8.4 \mathrm{~Hz}), 8.49(1 \mathrm{H}, \mathrm{s}), 8.65$ $(1 \mathrm{H}, \mathrm{d}, J=8.4 \mathrm{~Hz})$; MS $m / z 338.2(\mathrm{M}+1)$.

$N$-[2-(4-Chlorophenoxy)phenyl]-2-methylbenzamide (9). Yellow solid. Yield: 57.4\%. ${ }^{1} \mathrm{H}$ NMR (400 MHz, $\mathrm{CDCl}_{3}$ ): $\delta 2.48(3 \mathrm{H}, \mathrm{s}), 6.80(1 \mathrm{H}, \mathrm{d}, J=8.4 \mathrm{~Hz}), 6.96(1 \mathrm{H}, \mathrm{d}, J=8.4 \mathrm{~Hz})$, 7.05-7.07 (1H, t), 7.21-7.24 (2H, m), $7.29(2 \mathrm{H}, \mathrm{d}, J=8.0 \mathrm{~Hz})$, $7.50(2 \mathrm{H}, \mathrm{d}, J=2.4 \mathrm{~Hz}), 7.76(2 \mathrm{H}, \mathrm{d}, J=8.4 \mathrm{~Hz}), 8.49(1 \mathrm{H}, \mathrm{s}), 8.65$ $(1 \mathrm{H}, \mathrm{d}, J=8.8 \mathrm{~Hz}) ; \mathrm{MS} m / z 338.2(\mathrm{M}+1)$.

$\mathrm{N}$-[2-(2,4-Dichlorophenoxy)phenyl]-2-methylbenzamide (10). Brown solid. Yield: 66.4\%. ${ }^{1} \mathrm{H}$ NMR (400 MHz, $\mathrm{CDCl}_{3}$ ): $\delta 2.48(3 \mathrm{H}, \mathrm{s}), 6.80(1 \mathrm{H}, \mathrm{d}, J=8.4 \mathrm{~Hz}), 6.99(1 \mathrm{H}, \mathrm{d}, J=8.0 \mathrm{~Hz})$, 7.03-7.07 (1H, t), 7.19-7.24 (2H, m), $7.29(2 \mathrm{H}, \mathrm{d}, J=8.4 \mathrm{~Hz})$, $7.50(1 \mathrm{H}, \mathrm{d}, J=2.4 \mathrm{~Hz}), 7.76(2 \mathrm{H}, \mathrm{d}, J=8.4 \mathrm{~Hz}), 8.49(1 \mathrm{H}, \mathrm{s}), 8.65$ $(1 \mathrm{H}, \mathrm{d}, J=8.4 \mathrm{~Hz}) ; \mathrm{MS} m / z 394.2(\mathrm{M}+\mathrm{Na})$.

$\mathrm{N}$-[2-(2-Methylphenoxy)phenyl]-2-methylbenzamide (11). Yellow solid, Yield: 78.1\%. ${ }^{1} \mathrm{H}$ NMR $\left(400 \mathrm{MHz}, \mathrm{CDCl}_{3}\right): \delta 2.26$ (3H, s), $2.48(3 \mathrm{H}, \mathrm{s}), 6.92(1 \mathrm{H}, \mathrm{d}, J=8.4 \mathrm{~Hz}), 7.02-7.05(1 \mathrm{H}, \mathrm{m})$, 7.19-7.24 (3H, m), $7.30(1 \mathrm{H}, \mathrm{m}), 7.39(2 \mathrm{H}, \mathrm{d}, J=8.4 \mathrm{~Hz}), 7.60$ $(1 \mathrm{H}, \mathrm{d}, J=8.8 \mathrm{~Hz}), 7.72(2 \mathrm{H}, \mathrm{d}, J=8.0 \mathrm{~Hz}), 8.49(1 \mathrm{H}, \mathrm{s}), 8.65(1 \mathrm{H}$, d, $J=8.8 \mathrm{~Hz})$; MS $m / z 318.2(\mathrm{M}+1)$.

$\mathrm{N}$-[2-(4-Methoxyphenoxy)phenyl]-2-methylbenzamide (12). Yellow solid. Yield: $84.6 \% .{ }^{1} \mathrm{H} \mathrm{NMR}\left(400 \mathrm{MHz}, \mathrm{CDCl}_{3}\right)$ : $\delta 2.34(3 \mathrm{H}, \mathrm{s}), 2.48(3 \mathrm{H}, \mathrm{s}), 6.92(1 \mathrm{H}, \mathrm{d}, J=8.4 \mathrm{~Hz}), 7.06(1 \mathrm{H}$, m), 7.21-7.24 (3H, m), $7.30(1 \mathrm{H}, \mathrm{m}), 7.39(2 \mathrm{H}, \mathrm{d}, J=8.4 \mathrm{~Hz})$, $7.60(1 \mathrm{H}, \mathrm{d}, J=8.0 \mathrm{~Hz}), 7.73-7.77(2 \mathrm{H}, \mathrm{d}, J=8.4 \mathrm{~Hz}), 8.49(1 \mathrm{H}$, s), $8.65(1 \mathrm{H}, \mathrm{d}, J=8.4 \mathrm{~Hz})$; MS $m / z 318.3(\mathrm{M}+1)$.

$\mathrm{N}$-[2-(2,4-Dichlorophenoxy)phenyl]-2-nitrobenzamide (13). Gray solid. Yield: $45.8 \% .{ }^{1} \mathrm{H}$ NMR (400 $\left.\mathrm{MHz}, \mathrm{CDCl}_{3}\right)$ : $\delta 6.80(1 \mathrm{H}, \mathrm{d}, J=8.4 \mathrm{~Hz}), 6.99(1 \mathrm{H}, \mathrm{d}, J=8.0 \mathrm{~Hz}), 7.03-7.07$ $(1 \mathrm{H}, \mathrm{t}), 7.31-7.34(2 \mathrm{H}, \mathrm{m}), 7.41(2 \mathrm{H}, \mathrm{d}, J=8.0 \mathrm{~Hz}), 7.58(1 \mathrm{H}$, $\mathrm{d}, J=2.0 \mathrm{~Hz}), 7.86(2 \mathrm{H}, \mathrm{d}, J=8.4 \mathrm{~Hz}), 8.45(1 \mathrm{H}, \mathrm{s}), 8.65(1 \mathrm{H}, \mathrm{d}$, $J=8.8 \mathrm{~Hz}) ; \mathrm{MS} m / z 425.0(\mathrm{M}+\mathrm{Na})$.

$\mathrm{N}$-(2-Phenoxyphenyl)-2-chlorobenzamide (14). Yellow solid. Yield: $62.7 \% .{ }^{1} \mathrm{H}$ NMR $\left(400 \mathrm{MHz}, \mathrm{CDCl}_{3}\right): \delta 6.85(1 \mathrm{H}, \mathrm{d}$, $J=8.4 \mathrm{~Hz}), 6.99(1 \mathrm{H}, \mathrm{d}, J=8.4 \mathrm{~Hz}), 7.05-7.09(3 \mathrm{H}, \mathrm{m}), 7.15-7.18$ $(2 \mathrm{H}, \mathrm{m}), 7.27(2 \mathrm{H}, \mathrm{d}, J=8.4 \mathrm{~Hz}), 7.48(1 \mathrm{H}, \mathrm{d}, J=2.0 \mathrm{~Hz}), 7.71$ $(2 \mathrm{H}, \mathrm{d}, J=8.0 \mathrm{~Hz}), 8.50(1 \mathrm{H}, \mathrm{s}), 8.63(1 \mathrm{H}, \mathrm{d}, J=8.8 \mathrm{~Hz}) ; \mathrm{MS} m / z$ $324.2(\mathrm{M}+1)$.

$\mathrm{N}$-[2-(2-Chlorophenoxy)phenyl]-2-chlorobenzamide (15). Pale yellow solid. Yield: $75.8 \% .{ }^{1} \mathrm{H}$ NMR $\left(400 \mathrm{MHz}, \mathrm{CDCl}_{3}\right): \delta$ $6.85(1 \mathrm{H}, \mathrm{d}, J=8.4 \mathrm{~Hz}), 6.99(1 \mathrm{H}, \mathrm{d}, J=8.4 \mathrm{~Hz}), 7.05-7.09(1 \mathrm{H}$, m), 7.10-7.13 (1H, t), 7.15-7.18 (2H, m), $7.26(2 \mathrm{H}, \mathrm{d}, J=8.4 \mathrm{~Hz})$, $7.48(1 \mathrm{H}, \mathrm{d}, J=2.0 \mathrm{~Hz}), 7.71(2 \mathrm{H}, \mathrm{d}, J=8.4 \mathrm{~Hz}), 8.50(1 \mathrm{H}, \mathrm{s}), 8.63$ $(1 \mathrm{H}, \mathrm{d}, J=8.8 \mathrm{~Hz})$; MS $m / z 358.0(\mathrm{M}+1)$.

$\mathrm{N}$-[2-(4-Chlorophenoxy)phenyl]-2-chlorobenzamide (16). Pale yellow solid. Yield: 73.2\%. ${ }^{1} \mathrm{H}$ NMR $\left(400 \mathrm{MHz}, \mathrm{CDCl}_{3}\right): \delta$ $6.90(1 \mathrm{H}, \mathrm{d}, J=8.4 \mathrm{~Hz}), 7.00(1 \mathrm{H}, \mathrm{d}, J=8.4 \mathrm{~Hz}), 7.04-7.06(1 \mathrm{H}$, $\mathrm{m}), 7.13(1 \mathrm{H}, \mathrm{t}), 7.18-7.21(2 \mathrm{H}, \mathrm{m}), 7.29(2 \mathrm{H}, \mathrm{d}, J=8.4 \mathrm{~Hz}), 7.50$ $(1 \mathrm{H}, \mathrm{d}, J=2.4 \mathrm{~Hz}), 7.71(2 \mathrm{H}, \mathrm{d}, J=8.0 \mathrm{~Hz}), 8.48(1 \mathrm{H}, \mathrm{s}), 8.65(1 \mathrm{H}$, d, $J=8.8 \mathrm{~Hz})$; MS $m / z 358.0(\mathrm{M}+1)$. 


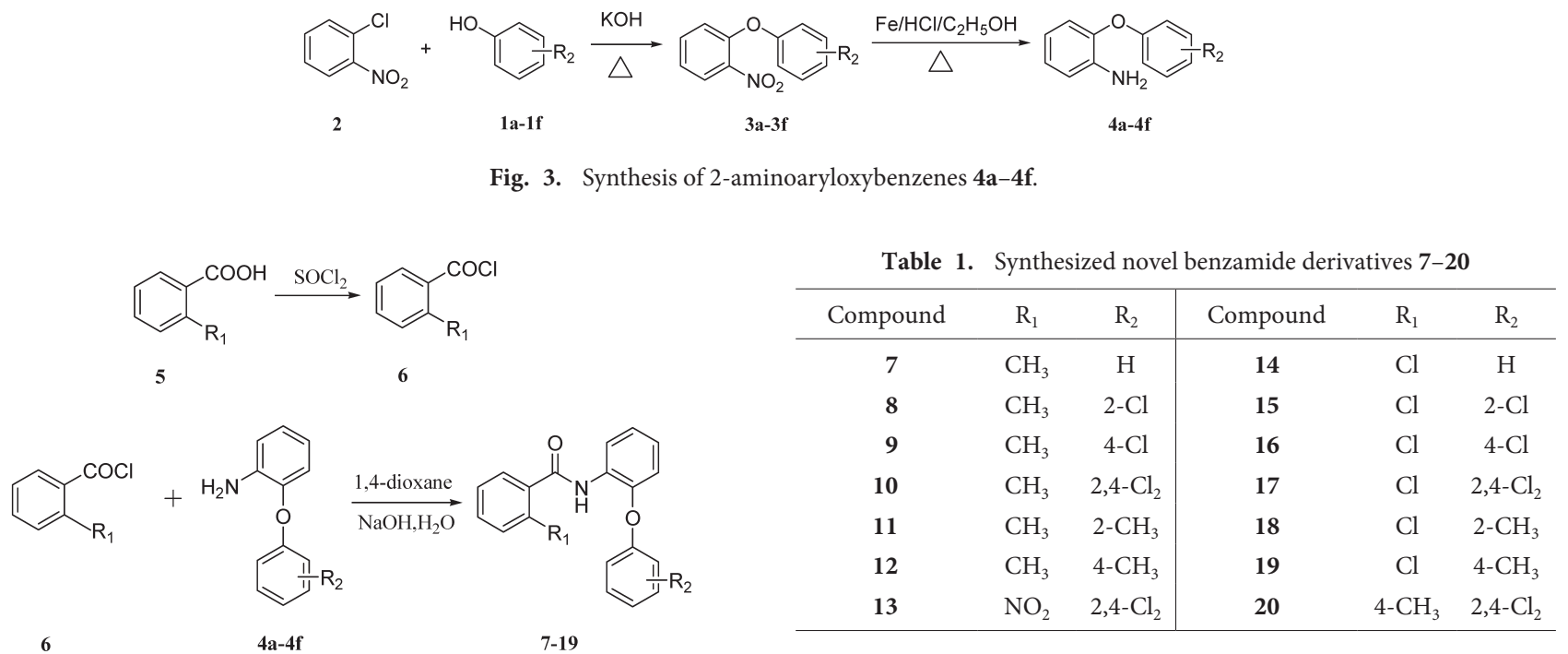

Fig. 4. Synthesis of target compounds 7-19.

$\mathrm{N}$-[2-(2,4-Dichlorophenoxy)phenyl]-2-chlorobenzamide (17). Yellow solid. Yield: 65.6\%. ${ }^{1} \mathrm{H}$ NMR $\left(400 \mathrm{MHz}, \mathrm{CDCl}_{3}\right)$ : $\delta 6.85(1 \mathrm{H}, \mathrm{d}, J=8.4 \mathrm{~Hz}), 6.99(1 \mathrm{H}, \mathrm{d}, J=8.4 \mathrm{~Hz}), 7.05(1 \mathrm{H}$, t), 7.15-7.18 $(2 \mathrm{H}, \mathrm{m}), 7.26(2 \mathrm{H}, \mathrm{d}, J=8.4 \mathrm{~Hz}), 7.48(1 \mathrm{H}, \mathrm{d}$, $J=2.4 \mathrm{~Hz}), 7.71(2 \mathrm{H}, \mathrm{d}, J=8.4 \mathrm{~Hz}), 8.50(1 \mathrm{H}, \mathrm{s}), 8.63(1 \mathrm{H}, \mathrm{d}$, $J=8.8 \mathrm{~Hz}) ; \mathrm{MS} m / z 391.2(\mathrm{M}+1)$.

$N$-[2-(2-Methylphenoxy)phenyl]-2-chlorobenzamide (18). Yellow solid. Yield: 59.2\%. ${ }^{1} \mathrm{H}$ NMR $\left(400 \mathrm{MHz}, \mathrm{CDCl}_{3}\right)$ : $\delta 2.26(3 \mathrm{H}, \mathrm{s}), 6.85(1 \mathrm{H}, \mathrm{d}, J=8.4 \mathrm{~Hz}), 6.97(1 \mathrm{H}, \mathrm{d}, J=8.4 \mathrm{~Hz})$, 7.05-7.09 (2H, m), 7.15-7.18 (2H, m), 7.25-7.28 (2H, d, 8.8 Hz), $7.48(1 \mathrm{H}, \mathrm{d}, J=2.4 \mathrm{~Hz}), 7.71(2 \mathrm{H}, \mathrm{d}, J=8.8 \mathrm{~Hz}), 8.50(1 \mathrm{H}, \mathrm{s}), 8.63$ $(1 \mathrm{H}, \mathrm{d}, J=8.4 \mathrm{~Hz}) ; \mathrm{MS} m / z 338.0(\mathrm{M}+1)$.

$\mathrm{N}$-[2-(4-Methylphenoxy)phenyl]-2-chlorobenzamide (19). Yellow solid. Yield: $68.5 \%$. ${ }^{1} \mathrm{H}$ NMR $\left(400 \mathrm{MHz}, \mathrm{CDCl}_{3}\right): \delta 2.36$ $(3 \mathrm{H}, \mathrm{s}), 6.92(1 \mathrm{H}, \mathrm{d}, J=8.4 \mathrm{~Hz}), 7.06(1 \mathrm{H}, \mathrm{m}), 7.21-7.24(3 \mathrm{H}$, m), $7.28(1 \mathrm{H}, \mathrm{m}), 7.30-7.34(2 \mathrm{H}, \mathrm{d}, J=8.4 \mathrm{~Hz}), 7.50(1 \mathrm{H}, \mathrm{d}$, $J=2.4 \mathrm{~Hz}), 7.73-7.77(2 \mathrm{H}, \mathrm{d}, J=8.4 \mathrm{~Hz}), 8.49(1 \mathrm{H}, \mathrm{s}), 8.65(1 \mathrm{H}$, d, $J=8.8 \mathrm{~Hz})$; MS $m / z 338.0(\mathrm{M}+1)$.

$\mathrm{N}$-[2-(2,4-Dichlorophenoxy)phenyl]-4-methylbenzamide (20). Yellow solid. yield: 57.3\%. ${ }^{1} \mathrm{H} \mathrm{NMR} \mathrm{(400} \mathrm{MHz}, \mathrm{CDCl}_{3}$ ): $\delta 2.42(3 \mathrm{H}, \mathrm{s}), 6.80(1 \mathrm{H}, \mathrm{d}, J=8.4 \mathrm{~Hz}), 6.99(1 \mathrm{H}, \mathrm{d}, J=8.8 \mathrm{~Hz})$, 7.03-7.07 (2H, t), 7.19-7.24 (1H, m), $7.29(2 \mathrm{H}, \mathrm{d}, J=8.0 \mathrm{~Hz})$, $7.50(1 \mathrm{H}, \mathrm{d}, J=2.4 \mathrm{~Hz}), 7.76(2 \mathrm{H}, \mathrm{d}, J=8.4 \mathrm{~Hz}), 8.49(1 \mathrm{H}, \mathrm{s}), 8.63$ $(1 \mathrm{H}, \mathrm{d}, J=8.4 \mathrm{~Hz}) ; \mathrm{MS} m / z 372.2(\mathrm{M}+1)$.

\section{Biological assay}

\subsection{Assay of antifungal activity}

For preliminary evaluation of compounds 7-20 the antifungal tests of Rhizoctonia solani, Gibberella zeae, Valsa mali, Botrytis cirerea and Sphaceloma ampelimum were carried out using the plate growth rate method. ${ }^{23)}$ The fungi were obtained from the Institute of Pesticide and Crop Protection, Sichuan University.

The tested compounds were dissolved in acetone and added to a sterile agarized Czapek-Dox medium at $45^{\circ} \mathrm{C}$. In primary screenings compounds were used at a concentration of $20 \mathrm{mg} / \mathrm{L}$. The control sample contained only one equivalent of acetone. The media were poured onto $8 \mathrm{~cm}$ Petri dishes $(10 \mathrm{~mL}$ for each dish) and after 2 days were inoculated with $4 \mathrm{~mm}$ Potato Dextrose Agar (medium) discs of overgrown mycelium. The Petri dishes were incubated at $26^{\circ} \mathrm{C}$ in the dark. Two or 7 days after inoculation the diameters of the cultures were measured. The percentage of inhibition of fungal growth was determined by comparison between the development of fungi colonized on media containing compounds and on the control. Carbendazim and boscalid, the commercial fungicides, were used as a positive control. Three replicates of each test were carried out and results were examined statistically.

\subsection{Assay of insecticidal activity}

Insecticidal activity of compounds 7-20 against oriental migratory locusts was tested by the dipping method. ${ }^{24)}$ The results were compared with the activity of a commercial insecticide avermectin.

Fifty milligrams of the sample was weighed and dissolved in $1 \mathrm{~mL}$ of acetone. Then a $49 \mathrm{~mL}$ mixture of $1 \%$ Tween 80 and water was added into the solution and the mixture $(50 \mathrm{~mL}$, $1000 \mathrm{mg} / \mathrm{L}$ ) was obtained. In the meantime, a mixture of acetone : $1 \%$ Tween 80 solution=1:49 was used as a blank control solution. Fresh rice leaf $(10 \mathrm{~cm}$ in length) made by punch was immersed into the prepared test solution for $5 \mathrm{sec}$, then it was placed into the bag and 30 healthy locusts were catched into the bag. Finally, the bag was placed in a constant-temperature room $\left(28^{\circ} \mathrm{C}\right)$ and observed. The number of dead and live locusts was counted every $24 \mathrm{hr}$, and after 3 days, a corrected mortality rate was calculated.

\section{Results and Discussion}

\section{Chemistry}

The synthesis of intermediate and target compounds was performed as illustrated in Fig. 3, Fig. 4 and Table 1. To synthesize target compounds $\mathbf{7 - 1 9}$, the intermediates $\mathbf{4 a}-\mathbf{4 f}$ were prepared 
in two steps. First, compound $\mathbf{2}$ was reacted with compounds 1a-1f under $\mathrm{KOH}$ by substitution reaction to produce compounds $\mathbf{3 a}-\mathbf{3 f}$. Then compounds $\mathbf{3 a}-\mathbf{3} \mathbf{f}$ were reduced by the combined action of $\mathrm{Fe}$ and $\mathrm{HCl}$ to obtain compounds $\mathbf{4 a}-\mathbf{4 f}$.

Meanwhile compound 5 was reacted with $\mathrm{SOCl}_{2}$ to obtain compound $\mathbf{6}$. Finally, compound $\mathbf{6}$ was reacted with compounds $\mathbf{4 a}-\mathbf{4 f}$ by amidation to gain target compounds 7-19.

\section{Biological activity}

\subsection{In vitro antifungal activity}

The results of the antifungal activity of compounds 7-20, boscalid and carbendazim at $20 \mathrm{mg} / \mathrm{L}$ against $R$. solani, G. zeae, $V$. mali, B. cirerea and S. ampelimum are listed in Table 2, in which the antifungal activities are expressed as inhibition of growth. We compared the growth rate of fungi on a medium containing a vehicle with the growth rate of fungi on a pure medium. The result indicated that the vehicle for compounds showed no visible antifungal activity.

The results in Table 2 show that target compounds 7-19 were active against nearly five fungi at $20 \mathrm{mg} / \mathrm{L}$ except for compound 13. Most of compounds 7-19 showed very strong antifungal activities against $R$. solani and S. ampelimum. Specifically compound 17 displayed stronger antifungal activities against $S$. ampelimum than other compounds and the inhibition of growth of compound 17 reached 100\%.

By comparing the molecular structures of compound 13 with those of other compounds, we could see that the $\mathrm{R}_{1}$ group of compound 13 was a nitro group (a strongly electron-withdrawing group), however, the $\mathrm{R}_{1}$ group of other compounds was a methyl group (an electron-donating group) or a chlorine atom (a weakly electron-withdrawing group).
Meanwhile we discovered that when the $\mathrm{R}_{1}$ group was a methyl group, compound $\mathbf{8 , 9}$ or $\mathbf{1 0}$ containing an $\mathrm{R}_{2}$ group that was a chlorine atom shown better antifungal activities than compound 11 or 12 containing an $\mathrm{R}_{2}$ group that was a methyl group. For example, the inhibition of 8 against S. ampelimum was $84.64 \%$, but the inhibition of 11 was only $66.35 \%$. In addition, when the $\mathrm{R}_{1}$ group of compound 15,16 or 17 was a chlorine atom, compound $\mathbf{1 7}$ with two chlorine atoms in diphenyl ether moiety showed better antifungal activities than compounds $\mathbf{1 5}$ and $\mathbf{1 6}$ with one chlorine atom.

In addition, we synthesized compound $\mathbf{2 0}$ having a methyl group at the 4-position (Fig. 5). By comparing the antifungal activities of compounds $\mathbf{1 0}$ and $\mathbf{2 0}$, we could clearly see that compound 10 displayed better antifungal activities than compound 20. This result is also in accord with data reported before that ortho methyl group at the amide group enhanced the compound's antifungal activities. ${ }^{25)}$

To analyze the antifungal activities of our compounds, compounds 9, 16 and 17 with stronger antifungal activities against S. ampelimum were selected for further research and their $\mathrm{EC}_{50}$ values are listed in Table 3.

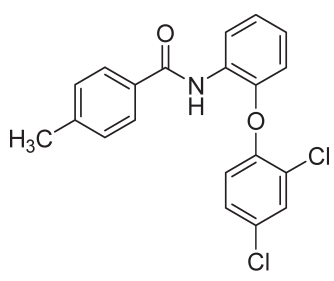

20

Fig. 5. Structure of target compound 20.

Table 2. Antifungal activities of benzamide derivatives $7-20$ at $20 \mathrm{mg} / \mathrm{L}$

\begin{tabular}{|c|c|c|c|c|c|}
\hline \multirow{2}{*}{ Compound } & \multicolumn{5}{|c|}{ Inhibition of growth (\%) } \\
\hline & R. solani & G. zeae & V. mali & B. cirerea & S. ampelimum \\
\hline 7 & 60.97 & 53.12 & 35.80 & 68.33 & 49.20 \\
\hline 8 & 74.82 & 46.97 & 68.20 & 54.20 & 84.64 \\
\hline 9 & 91.00 & 65.65 & 60.93 & 48.70 & 86.56 \\
\hline 10 & 89.20 & 52.70 & 74.21 & 66.67 & 86.95 \\
\hline 11 & 65.88 & 59.80 & 53.33 & 65.00 & 66.35 \\
\hline 12 & 76.71 & 40.33 & 44.20 & 58.33 & 61.85 \\
\hline 13 & 7.50 & 3.71 & 12.01 & 5.51 & 3.39 \\
\hline 14 & 71.61 & 17.90 & 18.94 & 4.72 & 75.00 \\
\hline 15 & 69.97 & 33.21 & 30.08 & 13.33 & 80.00 \\
\hline 16 & 72.19 & 49.10 & 41.40 & 21.01 & 93.33 \\
\hline 17 & 77.38 & 27.42 & 34.12 & 12.58 & 100 \\
\hline 18 & 53.33 & 22.00 & 11.93 & 5.51 & 63.33 \\
\hline 19 & 65.51 & 25.00 & 24.28 & 7.50 & 69.20 \\
\hline 20 & 15.75 & 1.61 & 8.85 & - & 12.93 \\
\hline Carbendazim & 94.00 & 91.10 & 100 & 49.50 & 38.00 \\
\hline Boscalid & 88.20 & 11.21 & 13.25 & 74.69 & 100 \\
\hline
\end{tabular}


Table 3. $\mathrm{EC}_{50}$ values of compounds 9,16 and 17

\begin{tabular}{cc}
\hline & S. ampelimum \\
\cline { 2 - 2 } Compound & $\mathrm{EC}_{50}(\mathrm{mg} / \mathrm{L})$ \\
\hline $\mathbf{9}$ & 3.19 \\
$\mathbf{1 7}$ & 1.70 \\
Carbendazim & 0.95 \\
Boscalid & 33.54 \\
\end{tabular}

Table 4. Insecticidal activities of compounds 7-20

\begin{tabular}{|c|c|c|c|c|c|}
\hline \multirow{2}{*}{ Compound } & \multicolumn{2}{|c|}{$\begin{array}{c}\text { Corrected mortality } \\
\text { rate }(\%)\end{array}$} & \multirow{2}{*}{ Compound } & \multicolumn{2}{|c|}{$\begin{array}{c}\text { Corrected mortality } \\
\text { rate }(\%)\end{array}$} \\
\hline & $\begin{array}{c}500 \\
\mathrm{mg} / \mathrm{L}\end{array}$ & $\begin{array}{l}1000 \\
\mathrm{mg} / \mathrm{L}\end{array}$ & & $\begin{array}{c}500 \\
\mathrm{mg} / \mathrm{L}\end{array}$ & $\begin{array}{l}1000 \\
\mathrm{mg} / \mathrm{L}\end{array}$ \\
\hline 7 & 8 & 36 & 15 & 8 & 36 \\
\hline 8 & 15 & 40 & 16 & 10 & 38 \\
\hline 9 & 6 & 38 & 17 & - & 18 \\
\hline 10 & 2 & 20 & 18 & - & 20 \\
\hline 11 & 8 & 36 & 19 & 12 & 40 \\
\hline 12 & 10 & 42 & 20 & 6 & 36 \\
\hline 13 & - & 25 & \multirow{2}{*}{\multicolumn{2}{|c|}{ Avermectin $(100 \mathrm{mg} / \mathrm{L})$}} & 100 \\
\hline 14 & - & 25 & & & \\
\hline
\end{tabular}

As shown in Table 3, the three compounds tested had higher antifungal activities against $S$. ampelimum. Additionally, each $\mathrm{EC}_{50}$ value of the three compounds was much less than that of carbendazim and was close to that of boscalid. Compound $\mathbf{1 7}$ had the best antifungal activity against $S$. ampelimum and its $\mathrm{EC}_{50}$ value reached $0.95 \mathrm{mg} / \mathrm{L}$. It is possible that compound $\mathbf{1 7}$ will become a potential lead compound for further structural optimization.

2.2. In vivo insecticidal activity

Because amide derivatives are also a kind of important insecticide, ${ }^{26)}$ in order to expand use of target compounds we tried to test their insecticidal activity and chose an easily obtained oriental migratory locust as a test object.

The insecticidal activity of compounds 7-20 (500 mg/L and $1000 \mathrm{mg} / \mathrm{L})$ and avermectin $(100 \mathrm{mg} / \mathrm{L})$ against the oriental migratory locust was studied. The corrected mortality rates for the compounds are listed in Table 4.

As shown in Table 4, compounds 7-20 had some insecticidal activities against the oriental migratory locust at $500 \mathrm{mg} / \mathrm{L}$ and $1000 \mathrm{mg} / \mathrm{L}$. However, their corrected mortality rates were lower than that of avermectin. It is observed that their insecticidal activities against locusts were poor, and their molecular structures need to be further optimized.

\section{Conclusion}

In summary, 14 novel benzamide derivatives 7-20 have been synthesized and evaluated for their antifungal activity against five plant pathogenic fungi (R. solani, G. zeae, V. mali, B. cirerea and $S$. ampelimum) and insecticidal activity against the oriental migratory locust. The results showed that some of the synthesized compounds exhibited strongly antifungal activities at $20 \mathrm{mg} / \mathrm{L}$. Most of benzamide derivatives showed excellent activities against $R$. solani and S. ampelimum. Compound 17 showed the strongest activity against $S$. ampelimum $\left(\mathrm{EC}_{50}=0.95 \mathrm{mg} / \mathrm{L}\right)$, close to the activity of boscalid. Furthermore, these preliminary results are promising and beneficial for further studies in developing new and more effective fungicides in the agrochemical field. Further structural modification and biological evaluation of our compounds are ongoing in our laboratory.

\section{Acknowledgements}

This study was supported by Hi-Tech Research and Development of China (863 program, 2011AA10A202-3), National Natural Science Foundation of China (31272068), National Key Technology R\&D Program of China (2011BAE06B01-23) and Applied Basic Research Program of Sichuan Province (2014JY0063) for financial support, and is grateful to Sichuan University Analytical and Testing Center for NMR spectroscopic analysis.

\section{References}

1) M. J. Gilbert, C. R. Thornton, G. E. Wakley and N. J. Talbot: Nature 440, 535-539 (2006).

2) L. P. Partida-Martinez and C. Hertweck: Nature 437, 884-888 (2005).

3) P. E. Russell: J. Agric. Sci. 143, 11-25 (2005).

4) M. T. McGrath: Plant Dis. 85, 236-245 (2001).

5) C. Lamberth, S. Jeanmart, T. Luksch and A. Plant: Science 341, 742746 (2013).

6) J. C. Yang, J. B. Zhang, B. S. Chai and C. L. Liu: Agrochemicals 47, 6-9 (2008).

7) W. Krämer, U. Schirmer, P. Jeschke and M. Witschel: "Modern Crop Protection Compounds," Wiley-VCH Verlag \& Co. KGaA, Weinheim, 2012.

8) Q. C. Huang: World Pestic. 26, 23-27 (2004).

9) P. Leroux: Pestic. Sci. 47, 191-197 (1996).

10) H. Jin, S. Chen, R. T. Hou, Y. L. Wang, S. H. Chen and Z. R. Yang: Chin. J. Org. Chem. 26, 1424-1428 (2006).

11) Y. Xin, H. Jin, R. T. Hou, L. Chen, F. L. Chen, K. Q. Wu, Y. L. Wang and Z. R. Yang: Chem. Res. Appl. 18, 1346-1348 (2006).

12) H. Xu, K. Z. Jian, Q. Guan, F. Ye and M. Lv: Chem. Pharm. Bull. 55, 1755-1757 (2007).

13) H. Q. Gao, L. N. Zhou, S. X. Cai, G. Zhang, T. Zhu, Q. Gu and D. Li: J. Antibiot. 66, 539-542 (2013).

14) Y. Zhang, X. M. Li, Z. Shang, C. S. Li, N. Y. Ji and B. G. Wang: J. Nat. Prod. 75, 1888-1895 (2012).

15) J. K. In, M. S. Lee, J. E. Yang, J. H. Kwak, H. Lee, S. K. Boovanahalli, K. Lee, S. J. Kim, S. K. Moon, S. Lee, N. S. Choi, S. K. Ahn and J. K. Jung: Bioorg. Med. Chem. Lett. 17, 1799-1802 (2007).

16) Y. Kohno, N. Ando, T. Tanase, K. Kuriyama, S. Iwanami and S. Kudou: WO 2003/029184 (2003).

17) S. Q. Shan, A. C. Lockhart, W. Y. Saito, A. M. Knapp, K. R. Laderoute and M. W. Dewhirst: Clin. Cancer Res. 7, 2590-2596 (2001).

18) S. H. Chen and C. Luo: West China J. Pharm. Sci. 13, 180 (1998).

19) S. Q. Yan, T. Appleby, E. Gunic, J. H. Shim, T. Tasu, H. Kim, F. Rong, H. M. Chen, R. Hamatake, J. Z. Wu, Z. Hong and N. H. Yao: Bioorg. Med. Chem. Lett. 17, 28-33 (2007).

20) Z. Y. Yu, G. Y. Shi, Q. Sun, H. Jin, Y. Teng, K. Tao, G. Zhou, W. Liu, F. 
Wen and T. P. Hou: Eur. J. Med. Chem. 44, 4726-4733 (2009).

21) C. H. Park and R. S. Givens: J. Am. Chem. Soc. 119, 2453-2463 (1997).

22) C. F. Koelsch: J. Am. Chem. Soc. 53, 304-305 (1931).

23) H. Jin, Y. C. Geng, Z. Y. Yu, K. Tao and T. P. Hou: Pestic. Biochem.
Physiol. 93, 133-137 (2009).

24) L. Chen, X. L. Wang, T. Lu and T. P. Hou: Pest Manag. Sci. 63, 928934 (2007)

25) G. A. White: Pestic. Biochem. Physiol. 31, 129-145 (1988).

26) A. Jeanguenat: Pest Manag. Sci. 69, 7-14 (2013). 